\title{
Marine Bioinvasions: The Alteration OF MARINE ECOSYSTEMS BY NONINDIGENOUS SPECIES
}

\author{
By James T. Carlton
}

Empty of cargo, the

ship ballasted

up-pumping or

gravitating the

brackish river water

under the ship into

its ballast tanks and

into a large central

cargo hold.

\begin{abstract}
$\mathrm{S}$ a load of wheat or iron ore, bound for a Russian port on the Black Sea. Perhaps it was winter, and the vessel needed more weight to keep it down in stormy seas. Or perhaps the vessel was "high on the nose." and needed extra weight to keep its bow down just a little more. The ship "ballasted up," pumping water into its bottom ballast tanks, and adding another 1.000 metric tons to a forepeak tank. The voyage went well; cargo and water were released on the north shore of the Black Sea, 22 days later.

In the fall of 1982. while towing a meter net for routine plankton sampling, a Russian oceanographic research vessel captured a 5-cm-long comb jellyfish previously unknown in the Black Sea. It was identified in Moscow as the American ctenophore Mnemiopsis leidyi. a common species from Cape Cod to Brazil (Vinogradov et al., 1989). By 1988 the standing stock of Mnemiopsis was calculated in terms of hundreds of thousands of metric tons. The comb jelly is well-known as an insatiable consumer of zooplankton. By 1989. anchovy (Engratis encrasicolus) landings had fallen from hundreds of thousands of tons to tens of thousands of tons (Harbison and Volovik. 1994).
\end{abstract}

Sometime in 1984, perhaps, a bulk cargo vessel departed the dock in a Chinese river port. headed for California to load wood products. Empty of cargo. the ship ballasted up-pumping or gravitating the brackish river water under the ship into its ballast tanks and into a large central cargo hold. With 25,000 metric tons of water aboard. the ves-

James T. Carlton. Professor of Marine Sciences, Williams College. Director, The Maritime Studies Program, William. College-Mystic Seaport Muscum. P.O. Box 6000, 75 Greenmanville Ave.. Mystic. Connecticut 06355. USA: telephone: 860-572-5359: FAX: 860-572-5329: c-mail: james.t.carlton (a'williams.edu sel could safely head for the open sea and a 14day crossing to a brackish water port in the northern part of San Francisco Bay. Once in the Bay. most of the Asian ballast water was to be pumped out, making "room"-in terms of both weight and space-for 30,000 metric tons of cargo.

In October 1986, a marine biology class, taking benthic grab samples in shallow water in the northern part of San Francisco Bay, found a small clam new to the Bay-a $2.5 \mathrm{~cm}$ long, wrinkly skinned bivalve later to be identified as the brackish water corbula Potamocorbula amurensis. By 1988 the standing stock of Potamocorbula reached 10,000 individuals per square meter (Carlton et al., 1990). By 1990 the spring phytoplankton bloom in the north Bay had essentially disappeared (Alpine and Cloern, 1992).

In 1985-or a year or two earlier-another bulk cargo vessel cast off lines in a Black Sea port for a month's voyage to the Great Lakes, to load wheat. In full freshwater ballast, the vessel was ready for a long voyage across the Mediterranean and up through the North Atlantic Ocean. Perhaps it was summer or fall (the lakes are closed for the entry of seagoing vessels in the middle of winter), and the waters of the Great Lakes were relatively warm-warm enough so that the plankton in the Black Sea ballast water would not die immediately from the stress of freezing water. Arriving in western Lake Erie-or while passing through Lake St. Clair, a small body of water between Lakes Erie and Huron-the ship discharged its ballast water.

On June 1. 1988, biologists pulling up benthic grabs from the floor of Lake St. Clair brought up a clump of bivalve mollusks new to the Great Lakes. By 1990 the zebra mussel Dreissena polymorpha-whose arrival in North America had been predicted since the 1920 s-occurred by the tens, and even the hundreds of thousands. per square meter on virtually every submerged hard substrate in the shallow waters of Lakes Huron 
and Erie (Mills et al., 1993). Water pipes 1.0 meter in diameter were narrowed to a $30-\mathrm{cm}$ core, the remainder of the pipe being a thick layer of zebra mussels.

On a spring day in May 1996 a bulk cargo vessel, or a container ship. or some other type of vessel, takes on water in San Francisco Bay that will be discharged two days later in Puget Sound. The Bay, that day, is rich with invertebrate larvae-the larvae of the clam Potamocorbula, or the larvae of the recently introduced Atlantic green crab Carcinus maenas, or the larvae of the latest invader, the Chinese mitten crab Eriocheir sinensis. None of these species now occur in Puget Sound.

Despite the above stories of the invasions of San Francisco Bay, the Black Sea, or the Great Lakes, is the captain of this ship ballasting up on this May day aware - in even the broadest senseof the potential contents of his ballast "cargo"? And even if he were (and chances are he"s not). what could he do about it?

Biological invasions in the sea consist of natural range expansions (that is. the often predictable ebb and flow of organisms due to changing climates or currents) and human-mediated introductions. The latter are usually unpredictable, and, because of the transport vectors discussed below, independent of the natural barriers of space and time (Carlton. 1987, 1989). Thus it is that a Japanese shore crab can appear in New Jersey, or an Australian barnacle in England, or a Chesapeake Bay comb jellyfish in the Black Sea.

Introductions of nonindigenous marine organisms by human activities are not new. We have been changing the face of coastal zone biotas for centuries, if not millennia, through the insertion of nonnative animals and plants. Peterson et al. (1992) have discussed the possibility that Viking explorers brought the North American clam Mya arenaria back to Europe as early as the 13th century. It appears too, that Portuguese traders may have intentionally brought the Japanese oyster Crassostrea gigas back to southern Europe in the 15 th century - where it was subsequently described as a new species. Crassostrea angulata, under which name it remains today (Edwards, 1976). By the 13th and 14th centuries, wooden vessels had set into motion the transglobal dispersal of wood-boring shipworms (teredinid hivalves) and gribbles (isopod crustaceans), in patterns that render discerning their aboriginal distributions extraordinarily difficult.

That organisms naturally drifted in wood along continental margins for eons is unquestionable: that they drifted in wood from southern Australia to the North Atlantic Ocean, and survived that voyage (if indeed it could even take place) over a period of several years, is not as clear. That thousands of wooden ships, their hulls riddled with boring organisms and covered with thick mats of fouling organisms, moved between these two regions in a matter of weeks or months, is wellknown.

The deep burrows created by wood-boring organisms in sailing vessels served as ocean-going refuges for many other mobile organisms, organisms that would be swept off the outer hull of the ship in the normal course of operations-animals such as crabs. shrimp. and small fish. The level of shipworm activity in tropical waters was sufficiently well-known to the British Admiralty by the 16th century that English ships were advised-indeed forbidden - to go into certain South American waters. The hulls themselves supported massive fouling communities (including hydroids. mussels, sea squirts, sea weeds, and scores of other organisms) that in turn provided intricate habitats for many nestling organisms typically not associated with such communities. such as clams or worms more normally found living in soft harbor muds, or mussels more typically associated with salt marshes, all of whose larvae could and do settle into thick fouling beds. Although we can "picture" such communities, based on studying modern fouling assemblages, there are no data that indicate just how diverse fouling communities were on ancient sailing vessels. Some insights have been gained, however, by studying fouling communities on modern-day replicas of historical vessels, whose sailing patterns mimic in part those of ancient voyages (Carlton and Hodder. 1995).

The transport of living organisms went on, too, deep inside the ship. Almost always before the 1880 s, but running well into the 1920 s, vessels carried rock and sand for ballast (and an amazing diversity of other heavy materials as well, ranging from old roof tiles to scrap metal), and this ballast was discharged on shores around the world (Carlton, 1992c). Carried in this maritime ballast were numerous shore-dwelling organisms, including beach plants, shore-hopping talitrid amphipods, and insects. Lindroth (1957), for example, in a scholarly and elegant treatise, traced the role of ships' ballast and the subsequent introduction of European beetles to North America. The Chilean-New Zealand sandhopper Transorchestia chiliensis was brought by beach ballast to the Oakland Estuary in San Francisco Bay presumably sometime in the late 19th or early 20 th centuries. and today survives (as the only known population of the subspecies T. c. enigmatica) on a 100-m stretch of shoreline on an urbanized lake in the middle of the City of Oakland.

Rock ballast may have been the means, too, by which the common European shore periwinkle Littorina littorea found its way in modern times to North America. although this snail is also a prime candidate for intentional release by European

\section{Biological invasions}

in the sea consist of natural range

expansions ... . and

human-mediated

introductions. 
colonists as a new coastal food resource, because it was for centuries (and regionally remains) a popular food item in western Europe.

The arrival of Littorina littorea in America in the 1840s further illustrates that introductions are not limited to bays, ports, and harbors- the urbanized aquatic "weedy lots." Littorina colonized rocky shores, marshes, and mudflats from Newfoundland to New Jersey in 40 years, and subsequently became the characteristic tidepool snail of New England (Brenchley and Carlton, 1983). In turn, Littorina changed the face of the rocky shores, profoundly altering the expression of both plant and animal communities (Lubchenco, 1978; Brenchley and Carlton, 1983; Carlton, 1992b). In the mid-19th century, the Indian Ocean wood boring isopod Sphaeroma terebrans began invading the mangrove communities of South, Central, and southern North America (Carlton and Ruckelshaus, 1996). In the 1950s, the Indo-Pacific mantis shrimp (stomatopod) Gonodactylus aloha was introduced to Hawaii, displacing the native species Pseudosquilla ciliata (Kinzie, 1984) on shallow coral reefs. In the 1980s, the Mediterranean mussel Mytilus galloprovincialis colonized the open wave-swept rocky shores of South Africa (Branch et al., 1991). Forty years earlier it had begun to occupy similar habitats in southern California.

After 500 years of seagoing vessels moving in every conceivable pattern and touching upon virtually every kilometer of coastline of the inhabited world, discerning the natural patterns of distributions of the thousands of species that could have been carried is thus difficult. This work requires retrospective time-based (paleontological, archeological, and historical) studies, spatial (biogeographic) studies, and a combination of both (evolutionary studies, looking at probable species relationships, and using molecular genetic techniques to "track" dispersal routes and the links between peripheral, disjunct populations and possible parental stocks).

Such work is tedious and time-consuming, and requires a species-by-species approach, but such work is slowly revealing which species in some communities are introduced and which are native (Carlton and Iverson, 1981; Meehan et al., 1989; Chapman and Carlton, 1991; Geller et al., 1993), thereby permitting us to begin to reconstruct the aboriginal nature of certain marine communities. That much of the reorganization of these communities occurred before the first biological surveys took place, and before Linnaeus and others even began bestowing Latin names onto animals and plants, guaranteed that the scale of this phenomenon would be-and largely still remains-buried in antiquity. In the meantime, the history of thousands of species that could have been transported by ships remains unknown. While by default such taxa are classically treated as "native," a more rigorous characterization is to think of such organ- isms as "cryptogenic," that is, neither clearly native or exotic (Carlton, 1996a) - as pieces of a yet unconstructed puzzle, as we try to assemble a picture of how modern coastal marine and estuarine communities came to be formed, and the extent to which they owe their modern diversity to humanmediated supplementation and transformation.

Although many details of the introduction of marine organisms remain to be resolved, it is clear that by the end of the 19th century an extensive reorganization of some fraction of the world's coastal marine biota had quietly and often cryptically taken place. The 20th century opened with an equally quiet yet profound change in global maritime commerce, a change that was to eventually set the stage for a vast new network of invasions.

In the 1880 s ship building technology changed, and the first serious commitment to iron ships was well underway. The existence of bulk-headed, metal-walled spaces, combined with motor-driven pumps, permitted ships to begin to switch from carrying rocks for ballast to carrying water for ballast (Carlton, 1985). Within 20 years, water ballast was in use by thousands of ships. Water was drawn into the vessel either by pumping, or by simply letting the water flow in by gravity until pumping was required.

And with that water plankton, fish, pieces of seaweed with attached organisms, and waterlogged pieces of wood rubbed off the piers, flowed into the vessel. For the first time in the history of human endeavor and the history of the ocean, large parcels of plankton-rich water were being transported virtually instantaneously across and between oceans. No longer were the vast expanses of the open ocean a barrier to the planktonic larvae or adults of most coastal-dwelling species, nor were continents a barrier to species living in the Atlantic or Pacific Oceans.

The first clear ballast water "signal" came from the North Sea, when in 1903 the Chinese diatom Biddulphia sinensis was discovered in Europe. The ballast game was afoot. By the 1910s the Chinese mitten crab Eriocheir appeared in German rivers; it too was thought to have been transported by ballast water. For the next 60 years transported species would dribble from the ballast faucet all over the world, but in apparently relatively small numbers (Carlton, 1985: Williams et al., 1988).

In the 1970s and 1980s, for reasons that remain at the doorstep of competing hypotheses (Carlton, 1996b), the number of invasions believed to be linked to the transport and discharge of ballast water began to blossom. Perhaps coastal waters were changing for the better due to several decades of intensive campaigns to improve water quality-thus making donor regions more diverse and recipient regions more susceptible to invasions. Perhaps the increased speed of vessels since World War II led to higher plankton survival, or 
perhaps the increased number of vessels carrying non-petroleum contaminated ballast water led to more successful inoculations. For whatever reasons. the world began to itch with new invasions of marine animals and plants. That it wasn't simply the appearance that there were more invasions, due to more scientists being aware of the phenomenon, or because of more thorough exploration. appears to be the case: in fact, since the 1970s, the number of scientists exploring the coastal zone and capable of identifying even common marine organisms has been in a steady, and sometimes steep, decline (Carlton, 1993; National Research Council, 1995).

Carlton (1985) reviewed what was known of ballast invasions and many of the available records up until the early 1980s (reporting of new invasions often lags behind actual introductions by several years). Soon thereafter, the ballast flood gates were about to open (Table 1)-the Chinese clam Potamocorbula was to be collected only $1 \mathrm{y}$ later in San Francisco Bay, the Eurasian zebra mussel Dreissena 2 y after that in the Great Lakes, and most of the western world was to first hear of the invasion of the Black and Azov Seas by the American comb jelly Mnemiopsis in 1989 (Vinogradov et al., 1989). In 1986 the first specimens of red-tide causing Japanese dinoflagellates were discovered in southern Australia, waters that receive vast amounts of ballast water from Japanese ports. Also in the 1980s the Japanese seaweed Undaria pinnatifida was discovered in the same waters (Sanderson, 1990), and in 1986 the Japanese starfish Asterias amurensis was found in Tasmania (Buttermore et al., 1994). All were linked to ballast water, with the dinoflagellates in particular being linked to the transport of their cyst stages in the large amounts of sediment that accumulate in ballast tanks and ballasted cargo holds (Hallegraeff, 1993).

In 1986 the Indo-Pacific swimming crab Charybdis helleri appeared in the Caribbean, apparently via ballast water by way of eastern Mediterranean populations (themselves established by coming through the Suez Canal); in 1995, it was discovered in Florida (Lemaitre, 1995). In 1988 the Japanese shore crab Hemigrapsus sanguineus appeared in New Jersey - an unexpected arrival given the much greater preponderance of ballast water released on the mid-Atlantic coast not from Asia but from Europe and the Mediterranean.

And in 1989 one of the more remarkable invasions seen in many decades appeared in France and Monaco in the northern Mediterranean: a form of the ubiquitous subtropical green algae Caulerpa taxifolia (Boudouresque et al., 1994). This alga now occupies many thousands of square meters of sea floor in the shallow sublittoral zone, in regions formerly supporting diverse arrays of other erect macroscopic organisms, such as sponges, gorgonians, and other seaweeds (A. Meinesz, personal communication). For many hundreds of meters in waters only 1-2 $\mathrm{m}$ deep along the shoreline of northern Italy, Caulerpa now forms "astroturf"like green sheets (JTC and A. Meinesz, personal observations, Imperia, Italy, June 1995). Caulerpa appears to owe its origins and its freedom in the Mediterranean not, however, to ballast water, but to releases from the aquarium industry.

Scores of other invasions have been recorded in the 1980s and 1990s from those countries with the remaining resources and taxonomic expertise to detect new invasions (Carlton and Geller. 1993). From scores of other coastal countries of the world, with few or no active marine ecological or taxonomic programs, the literature is silent on new species invasions.

It's May, 1996 and the ship noted earlier has finished ballasting in San Francisco Bay, about to take a load of plankton up to Puget Sound. Or perhaps the ship is in the Great Lakes, ballasting up zebra mussel larvae. now that America is a major donor region of zebra mussels. Or perhaps it is in a Tasmanian port, ballasting up the larvae of the seastar Asterias to be donated to another port elsewhere in the world. If told of what he is about to do, relative to the transport of exotic species, the ship captain may well wonder what the concern is: he's been moving ballast water for decades, and surely "everything that could have been introduced would have been introduced by now." But here our ability to predict fails the Captain.

That zebra mussels were released in the Great Lakes for decades before they were discovered by scientists in 1988 seems almost certain. That the Great Lakes-or American waters in generalwere "immune" to the invasion of the zebra mussel seemed like a tempting conclusion as of May, 1988. But as long as the corridor remains openor "fluid" in this case-we know that the potential for invasion also remains. A vessel may move a species between two ports for 100 years, and then the species "takes" in the 101 st year. One of the commonest fouling organisms of western Europe is the seasquirt Ascidiella aspersa. It seems probable that it has been on the bottoms of many vessels visiting American ports for almost 400 years. Why, then, did it appear in New England fouling communities in the mid-1980s?

With our ability thus being low to predict the relationship between the existence of a transport mechanism and the probability of introduction of any given species, a logical route is to reduce the scale of the mechanism. In 1990, Australia, Canada. and the United States brought before the United Nations International Maritime Organization (IMO) the issue of ballast water and the introduction of nonindigenous, particularly so-called "nuisance," species. As of 1996. IMO is considering amendments to the international regulations 
Table 1

\begin{tabular}{|c|c|c|}
\hline $\begin{array}{c}\text { Species } \\
\text { (Native Region) }\end{array}$ & $\begin{array}{c}\text { Introduced To } \\
\text { (Mcchanism of Introduction: } \\
\text { 1st Date of Collection) }\end{array}$ & Reference \\
\hline \multicolumn{3}{|l|}{ Chlorophyta } \\
\hline $\begin{array}{l}\text { Cauterpa taxifolia (subtropical regions) } \\
\text { (green alga) }\end{array}$ & $\begin{array}{l}\text { Mediterranean: France and Italy } \\
\text { (AQ: 1989) }\end{array}$ & Boudouresque et al., 1994 \\
\hline \multicolumn{3}{|l|}{ Rhodophyta } \\
\hline $\begin{array}{l}\text { Antithumnion nipponicum (Japan) } \\
\quad \text { (red alga) }\end{array}$ & $\begin{array}{l}\text { Long Island Sound: Connecticut } \\
\qquad \text { (BW/SF; 1986) }\end{array}$ & Foertch et al., 1995 \\
\hline \multicolumn{3}{|l|}{ Phaeophyta } \\
\hline Undaria pinnutifida (Japan) (kelp) & Australia (BW/SF: 1980s) & Sanderson, 1990 \\
\hline \multicolumn{3}{|l|}{ Dinotlagellata } \\
\hline $\begin{array}{l}\text { Alexandrium catenella (Japan) } \\
\text { (dinoflagellate) }\end{array}$ & Australia (BW: 1986) & Hallegraeff, 1993 \\
\hline \multicolumn{3}{|l|}{ Ctenophora } \\
\hline Mncmiopsis leidyi (Americas) (combjelly) & Black and Azov Seas (BW; 1982) & $\begin{array}{l}\text { Vinogradov et al. } 1989 \\
\text { Harbison and Volovik, } 1994\end{array}$ \\
\hline \multicolumn{3}{|l|}{ Annelida: Polychaeta } \\
\hline $\begin{array}{l}\text { Marenselleria viridis (North America) } \\
\text { (spionid worm) }\end{array}$ & Western Europe (BW; 1983) & Essink and Kleef. 1993 \\
\hline \multicolumn{3}{|l|}{ Mollusca: Bivalvia } \\
\hline $\begin{array}{l}\text { Perma perna (South America) } \\
\text { (brown mussel) }\end{array}$ & Gulf of Mexico: Texas (BW/SF: 1990) & Hicks and Tunnell. 1993 \\
\hline $\begin{array}{l}\text { Pinctada margaritifera (Tropical Pacific Ocean) } \\
\text { (pearl oyster)* }\end{array}$ & Florida (BW/SF; 1990) & $\begin{array}{l}\text { Chesler. 1994: } \\
\text { Carlton and Ruckelshaus, } 1990\end{array}$ \\
\hline $\begin{array}{l}\text { Potamocorbula cmurensis (Asia) } \\
\text { brackish water corbula) }\end{array}$ & San Francisco Bay (BW: 1986) & Carlton et al., 1990 \\
\hline Dreissena polymorpha (Eurasia; zebra mussel) & Great Lakes (BW; 1988) & Mills et al., 1993 \\
\hline Dreissena bugensis (Eurasia; quagga mussel) & Great Lakes (BW: 1990) & Mills et al.. 1993 \\
\hline \multicolumn{3}{|l|}{ Crustacea: Copepoda } \\
\hline $\begin{array}{l}\text { Pséudodiaptomus marinus (China, Japan) } \\
\text { (copepod) }\end{array}$ & San Francisco Bay (BW; 1986) & Orsi and Walter. 1991 \\
\hline Pscudodiaptomus forbesi (China) (copepod) & San Francisco Bay (BW; 1987 ) & Orsi and Walter, 1991 \\
\hline \multicolumn{3}{|l|}{ Crusticea: Isopoda } \\
\hline $\begin{array}{l}\text { Sphaerona quovanum (New Zealand) } \\
\text { (boring pillbug) }\end{array}$ & Oregon (SF; 1995) & Herein \\
\hline \multicolumn{3}{|l|}{ Crustacea: Cladocera } \\
\hline Bythotrephes cederstroemi (Eurasia) (water flea) & Great Lakes (BW; 1984) & Mills et al. 1993 \\
\hline \multicolumn{3}{|l|}{ Crustacea: Decapoda } \\
\hline Carcinus maenas (North Atlantic) (shore crab) & California (?; 1989-1990) & $\begin{array}{l}\text { Cohen et al.. 1995: } \\
\text { Grosholz and Ruiz. } 1995\end{array}$ \\
\hline Callinectes sapidus (Northwest Atlantic) (blue crab) ${ }^{*}$ & Hawaii (PR?; 1985) & Eldredge. 1995 \\
\hline Charybdis helleri (IndoPacific) (swimming crab) $\ddagger$ & Florida (BW/SF: 1945) & Lemaitre. 1995 \\
\hline Hemigrapsus sanguineus (Japan; shore crab) & New Jersey (BW: 1988) & McDermott, 1991 \\
\hline \multicolumn{3}{|l|}{ Bryozoa } \\
\hline Menhranipora membranacea (Europe: moss animal) & Maine to New York (BW: 1987) & Berman et al.. 1992 \\
\hline \multicolumn{3}{|l|}{ Echinodermata } \\
\hline Asterias annurensis (Japan) (North Pacific seastar) & Australia; Tasmania (BW/SF: 1986) & Buttermore et al., 1995 \\
\hline \multicolumn{3}{|l|}{ Chordata: Tunicata } \\
\hline Styela clava (Japan) (Stalked sea squirt)\$ & Oregon (SF; 1995) & Herein \\
\hline Ascidiella aspersa (Europe) (sea squirt) & $\begin{array}{l}\text { Massachusetts to Connecticut } \\
\text { (BW/SF; (a. 1985) }\end{array}$ & Carlton, 1993 \\
\hline \multicolumn{3}{|l|}{ Chordata: Pisces } \\
\hline Gymnocephalus cernutus (Europe) (ruffe) & Great Lakes (BW; 1987) & Mills et al., 1993 \\
\hline Proterorhinus marmoratus (Eurasia; goby) & Great Lakes (BW; 1990) & Mills et al.. 1993 \\
\hline Neogobious melanostomus (Eurasia: goby) & Great Lakes (BW: 1990) & Mills et al., 1993 \\
\hline
\end{tabular}

BW, in ships" ballast water; SF. in ships' fouling or boring; AQ, public aquarium release: PR. private release by individual.

* Not known if established.

† Previously known from Humboldt Bay. California to Baja California; discovered in 1995 in Coos Bay. Oregon.

$\$$ Previously known in 1987-1988 trom Cuba, Colombia, and Vene $2 u e l a$.

\$ Previously known from San Francisco Bay to San Diego Bay; discovered in 1993-1994 in Coos Bay by R. Emlet and A. Moran (personal communication, 1995).

(known as MARPOL) that govern marine pollution from ship-generated sources, amendments that would require vessels around the world to undertake ballast management practices.
These practices include releasing original ballast water in midocean. when and where it is safe to do so, and thus arriving in the destination port with planktonic organisms that could not survive in 
coastal waters. As exchange of ballast water would put ship and crew at risk under heavy weather conditions, alternative ballast management strategies are now being extensively studied by IMO and by the above countries. These focus on both "micromanagement" scenarios (asking ships not to ballast up "red water" or other discolored water next to them. as such water might represent a toxic dinoflagellate bloom) and to direct treatment of the water by mechanical, thermal, chemical or other means. Ballast management at all of these levels-from open-ocean exchange, to local control, to new ship technologywill provide the basis for extensively reducing ballast water introductions (Carlton et al., 1995).

How can invasions impact marine ecosystem function? Invasions can alter the energy flow, the species interactions, and virtually all other aspects of community structure. As noted earlier, the brackish water corbula Potamocorbula, along with a less abundant but earlier introduction, the Atlantic softshell clam Mya arenaria, are apparently responsible for extremely low chlorophyll levels in the water column in the northeastern portions of San Francisco Bay (Alpine and Cloern. 1992). The removal of one of the bases of the food chain-the phytoplankton-from large regions of San Francisco Bay obviously could have extensive impacts on the seasonal abundance of their predators, the herbivorous zooplankton (such as copepods and mysids) and. in turn. upon zooplanktivorous fish. Also noted earlier was the remarkable success of the Atlantic Ocean combjelly fish Mnemiopsis in the Black and Azov Seas. A carnivore, it consumes zooplankton (including larval fish) voraciously, and when it occurs in high densities, it is capable of removing most copepods from a given mass of estuarine water. In each case, the insertion of a single species into a relatively large ecosystem has fundamentally altered energy flow and subsequent species interactions. perhaps irreversibly. Invasions representing the same trophic guild can, in turn. produce similar profound effects. Cloern (1982) and Officer et al. (1982) thus provided compelling evidence that in south San Francisco Bay three species of introduced clams (from New England and from Japan) are also the primary controllers of phytoplankton biomass.

In other regions, species known to play an important ecosystem role in one region have become abundant in a new area, but their impact in the latter site may remain unknown or poorly understood. An example is the American Atlantic marsh mussel Arcuatula demissa (Geukensia demissa), a species known to be important in the biogeochemical cycling of phosphorus between the water column and sediments in Georgia marshes (Kuenzler, 1961). Arcuatula has been common to abundant in San Francisco Bay since the 1890s, and yet its role in processing phosphorus in that estuary remains unknown.

Not all invasions are inherently "bad." of course. Intentional releases such as the Atlantic striped bass Morone saxatilis in California in the 1870 s led to more than 100 years of popular sport fishing. Accidental releases such as the Japanese clam Venerupis philippinarum in British Columbia and the State of Washington in the 1930s (transported unintentionally with Japanese oysters) led to multi-million dollar shellfisheries resources now largely based in clam farms. These species have of course altered the ecosystems they are in. and neither species would likely be intentionally introduced today in the United States because of the concerns over the potential levels of such alterations.

Although intentional releases of nonnative species to enhance local fisheries or start new mariculture operations continues actively around the world (Carlton, 1992a), such releases are often of species whose biology and ecology are known to some extent, and thus we can enter into discussions over the wisdom of such releases, based on the available data and based on the predicted outcomes-both in terms of ecological impact and of resource development. Equally challenging are new research directions that will provide genetically altered species for fisheries enhancement, with the intent that such species be released in the wild.

But accidental releases-by such means as ballast water-play invasions roulette with potentially much higher stakes, because the species involved are not often not recognized as being present until after they have become well-established. That major finfish fisheries can be readily impacted is illustrated by the invasion of the comb jelly Mnemiopsis in the Black Sea and the demise of the anchovy fishery. Central American shrimp viruses transported in 1994-1995 to Texas coast shrimp facilities offer another example of such fisheries impacts. That marine and coastal protected areas are not immune to invasions is well illustrated by the diversity and predominance of introduced marine invertebrates and plants in some National Estuarine Research Reserves (Carlton, 1989).

Given the vast kaleidoscope of invasions around the world, what are the critical research needs at the close of the 20th century as we anticipate the potential of a new century of invasions? Key questions focus on the ecology, biogeography, prevention, and control of exotic species. In terms of ecology and biogeography, there are now many hundreds if not thousands of individual case histories of aquatic invasions, ranging from simple records to anecdotal descriptive accounts to, in rare cases, experimental studies. Coupled with these are growing data sets on specific transport vectors. A critical need exists to begin to elucidate patterns, if such exist, on how many, where, when, and why invasions have been relatively successful and unsuccessful, through comparisons of different marine provinces. An important focus will be to look at the resistance or susceptibility to invasions
That marine and

coastal protected

areas are not immune

to invasions is well

illustrated by the di-

versity and predomi-

nance of introduced

marine invertebrates

and plants in some

National Estuarine

Research Reserves 
in distinct communities within and between provinces.

Equally important is research to significantly slow the rate of invasions, by identifying those vectors that function to transport the preponderance of species and then by designing management interfaces to interrupt the vector with sophisticated quarantine barriers. These embody challenging problems: vector interruption does not necessarily mean disruption or cessation of the vector itself. Thus a major focus of prospective ballast water management technologies is to minimize the impact on ship speed. ship cargo handling, and ship port residency while maximizing the reduction of viable organisms transported. Finally, research on control mechanisms that seek to limit the spread and abundance of introduced species that are already well-established is virtually nonexistent for all but a few of the higher-profile (in terms of economic or other social impacts) species.

A result of decades of invasions is that, in regions such as San Francisco Bay or Long Island Sound or Puget Sound, the biota is now technically richer (often by scores or hundreds of species) in terms of the number of species that have been added since the mid-19th century. This phenomenon presents a perhaps confusing picture to the public and to governmental agencies relative to our normal celebrations that regions with "higher diversity" are in some manner "better." In turn, we know of no species that have been completely lost from these regions because of these invasions, although the abundance of the native species and how they interacted may be highly altered.

It is, in fact, the latter that we have lost. San Francisco Bay and hundreds of sites all over the world are apparently richer places in terms of the absolute number of species now present. But gone, and in many regions, only gone since the late 19 th century, are the original communities that inhabited these regions, and thus we are in fact far poorer in terms of natural biodiversity at the community and ecosystem level.

Our awareness of the scale of the rate of new invasions and of the role of specific transport vectors such as ballast water is perhaps the greatest tool and hope for future marine conservation strategies relative to minimizing future invasions. The introduction of zebra mussels in the Great Lakes precipitated national legislation in the United States on introduced aquatic organisms and on ballast management (Public Law 101-646. The Nonindigenous Aquatic Nuisance Prevention and Control Act of 1990). Thus perhaps one of the positive fallouts of the zebra mussel will be that there will be fewer invasions in the future.

There is still much to preserve and to cherish in the world's oceans. Reducing the number of invasions will do much to keep it that way.
References

Alpine. A.E. and J.E. Cloern, 1992: Trophic interactions and direct physical effects control phytoplankton biomass and production in an estuary. Limnol. Ocean., 37. 946-955.

Berman, J., L. Harris. W. Lambert, M. Buttrick and M. Dufresne, 1992: Recent invasions of the Gulf of Maine three contrasting ecological histories. Conserv. Biol.. 6 . $435-441$.

Boudouresque, C.-F., A. Meinesz and V. Gravez, 1994: Synthese des resultats du programme CCE LIFE "Expansion de l'algue verte tropicale Caulerpa taxifolia en Mediterrannee. First International Workshop on Caulerpa taxifolia. GIS Posidonie Publishers, Marseille Cedex, France, 11-25.

Brenchley. G.A. and J.T. Carlton. 1983: Competitive displacement of native mud snails by introduced periwinkles in the New England intertidal zone. Biol. Bull., 165. $54.3-558$.

Buttermore, R.E., E. Turner and M.G. Monice, 1994: The introduced northern Pacitic sea star Asterias amurensis in Tasmania. Memoirs of the Queensland Museum, 36. 21-25.

Carlton, J.T. 1985: Transoceanic and interoceanic dispersal of coastal marine organisms: the biology of ballast water. Ocean. Mar. Biol. Annu. Rev., 23, 313-371.

1987: Patterns of transoceanic marine biological invasions in the Pacific Ocean. Bull. Mar. Sci., 41 , $452-465$.

1984: Man's role in changing the face of the ocean: biological invasions and implications for conservation of near-shore environments. Conserv. Biol., 3, 265-27.3. 1992a: Dispersal of living organisms into aquatic ecosystems as mediated by aquaculture and fisheries activities. In: Dispersal of Living Organisms into Aquatic Ecosvistems. A. Rosenfield and R. Mann, eds. Maryland Sea Grant Publication, College Park, MD, 471 pp., $13-45$.

1992b: Introduced marine and estuarine mollusks of North America: an end-of-the-20th-century perspective. I. Shellfish Res., 11. 489-505.

1992:: Blue immigrants: the marine biology of maritime history. The Log (Mystic Seaport Museum, Mystic CT), 44, 31-36.

1993: Neoextinctions of marine invertebrates. Am. Zool., 33, 499-509.

1996a: Biological invasions and cryptogenic species. Ecology. In press.

1996b: Pattern, process. and prediction in marine invasion ecology. Biol. Consern., Special Issue. In press.

and J.B. Geller, 1996: Ecological roulette: the global transport of nonindigenous marine organisms. Science $261,78-82$.

and J. Hodder, 1995: Bingengraphy and dispersal of coastal marine organisms: experimental studies on a replical of a 16th-century sailing vessel. Mar. Biol., 121. 721-730.

and E.W. Iverson. 1981: Biogeography and natural history of Sphaeroma walkeri Stebbing (Crustacea: Isopoda) and its introduction to San Diego Bay. California. J. Natl. Hist. 15, 31-48.

D.M. Reid and H. van Leeuwen. 1995: Shipping study. The role of shipping in the introduction of nonindigenous aquatic organisms to the coastal waters of the United States (other than the Great Lakes) and an analysis of control options. The National Sea Grant College Program/Connecticut Sca Grant Project R/ES-6. Department of Transportation. United States Coast Guard, Washington. DC and Groton, Connecticut. Report CG-D-11-95. Government Accession Number ADA294809, 2 I3 pp. and Appendices A-I (122 pages). and M. Ruckelshaus, 1996: Nonindigcnous marine invertebrates and algae of Florida. In: Non-Indigenous Specie's in Florida: Patterns, Effects, and Management. 
D. Simberloff, D.C. Schmitz and T. Brown, eds. Island Press, Covelo, CA. In press.

. J.K. Thompson, L.E. Schemel and F.H. Nichols. 1990: Remarkable invasion of San Francisco Bay (California, USA) by the Asian clam Potamocorbula amurensis. I. Introduction and dispersal. Mar. Ecol. Prog. Ser., 66, 81-94.

Chapman, J.W. and J.T. Carlton, 1991: A test of criteria for introduced species: the global invasion by the isopod Synidotea laevidorsalis (Miers, 1881). J. Crust. Biol.. II, 386-400.

Chesler, J., 1994: Not just bilge water. Amer. Conch., 22, 13.

Cloern. J.E., 1982: Does the benthos control phytoplankton biomass in South San Francisco Bay? Mar. Ecol. Prog. Ser., 9, 191-202.

Cohen, A.N., J.T. Carlton and M.C. Fountain, 1995: Introduction. dispersal and potential impacts of the green crab Carcinus maenas in San Francisco Bay, California. Mar. Biol., 122, 225-237.

Edwards, C. 1976: A study in erratic distribution: the occurrence of the medusa Gonionemus in relation to the distribution of oysters. Advances in Marine Biology, 14, 251-284.

Eldredge, L.G., 1995: First record of the blue crab (Callinectes sapidus) in Hawaii (Decapoda: Brachyura). Occ. Pap. Bishop Mus., 42, 55-58.

Essink, K. and H.L. Kleef, 1993: Distribution and life cycle of the North American spionid polychaete Marenzelleria viridis (Verrill, 1873) in the Ems Estuary. Neth. J. Aquat. Ecol., 27, 237-246.

Foertch. J.F.. J.T. Swenarton and M. Keser, 1995: Introduction of a new Antithamnion to Long Island Sound. In: Proceedings of the Northeast Conference on Non-Indigenous Aquatic Nuisance Species. N. Balcom. ed. Publication Number CT-SG-95-04, Connecticut Sea Grant College Program, University of Connecticut. Groton, CT, 89 pp., 9.

Geller, J.B.. J.T. Carlton and D.A. Powers, 1993: Interspecific and intrapopulation variation in mitochondrial ribosomal DNA sequences of Mytilus spp. (Bivalvia: Mollusca). Mol. Mar. Biol. Biotech., 2, 44-50.

Grosholz, E.D. and G.M. Ruiz, 1995: Spread and potential impact of the recently introduced European green crab, Carcinus maenas, in central California. Mar. Biol., 122, 239-247.

Hallegraeff, G.M., 1993: A review of harmful algal blooms and their apparent global increase. Phycologia, 32, 79-99.

Harbison, G.R. and S.P. Volovik, 1994: The ctenophore Mnemiopsis leidyi, in the Black Sea: a holoplanktonic organism transported in the ballast water of ships. In: Nonindigenous Estuarine and Marine Organisms (NEMO). Proceedings of the Conference and Workshop, Seattle. Washington, April 1993. U.S. Department of Commerce, National Oceanic and Atmospheric Administration, 125 pp., 25-36.

Hicks, D.W. and J.W. Tunnell, 1993: Invasion of the south
Texas coast by the edible brown mussel Perna perna (Linnaeus, 1758). Veliger, 36, 92-94.

Kinzie, R.A., 1984: Aloha also means goodbye: a cryptogenic stomatopod in Hawaii. Pac. Sci., 38, 298-311.

Kuenzler, E.J., 1961: Phosphorus budget of a mussel population. Limnol. Ocean., 6, 400-415.

Lemaitre, R., 1995: Charybdis helleri (Milne Edwards, 1867), a nonindigenous portunid crab (Crustacea: Decapoda: Brachyura) discovered in the Indian River lagoon system of Florida. Proc. Biol. Soc. Wash., 108, 643-648.

Lindroth. C.H., 1957: The Faunal Connection Between Europe and North America. John Wiley and Sons, New York, $157 \mathrm{pp}$.

Lubchenco, J., 1978: Plant species diversity in a marine intertidal community: importance of herbivore food preference and algal competitive abilities. Am. Nat., 112, 23-39.

McDermott. J.J., 1991: A breeding population of the western Pacific crab Hemigrapsus sanguineus (Crustacea: Decapoda: Grapsidae) established on the Atlantic coast of North America. Biol. Bull., 181, 195-198.

Meehan, B.W., J.T. Carlton and R. Wenne, 1989: Genetic affinities of the bivalve Macoma balthica from the Pacific coast of North America: evidence for recent introduction and historical distribution. Mar. Biol., IO2, 235-241.

Mills, E.L., J.H. Leach, J.T. Carlton and C. Secor, 1993: Exotic species in the Great Lakes: a history of biotic crises and anthropogenic introductions. J. Great Lakes Res., 19, $1-54$.

National Research Council, 1995: Understanding marine biodiversity: a research agenda for the nation. National Academy Press, Washington, DC (ISBN 0-309-052254), $x i i+180 \mathrm{pp}$.

Officer, C.B., T.J. Smayda and R. Mann, 1982: Benthic filter feeding: a natural eutrophication control. Mar. Ecol. Progr. Ser., 9, 203-210.

Orsi, J.J. and T.C. Walter. 1991: Pseudodiaptomus forbesi and P. marinus (Copepoda: Calanoida), the latest copepod immigrants to California's Sacramento-San Joaquin estuary. Proc: 4th Intern. Conf. Copepoda, Bull. Plankton Soc. Japan, Special volume (1991). 553-562.

Petersen, K.S., K.L. Rasmussen, J. Heinemeler and N. Rud, 1992: Clams before Columbus? Nature. 359, 679.

Sanderson, J.C., 1990: A preliminary survey of the distribution of the introduced macroalga, Undaria pinnatifida (Harvey) Suringer on the east coast of Tasmania, Australia. Bot. Mar., 33, 153-157.

Vinogradov, M.E., E.A. Shushkina, E.I. Musayeva and P.Y. Sorokin, 1989: A newly acclimated species in the Black Sea: the ctenophore Mnemiopsis leidyi (Ctenophora: Lobata). Oceanology, 29, 220-224.

Williams, R.J., F.B. Griffiths, E.J. Van der Wal and J. Kelly, 1988: Cargo vessel ballast water as a vector for the transport of non-indigenous marine species. Estuarine Coastal Shelf Sci.. 26, 409-420. 